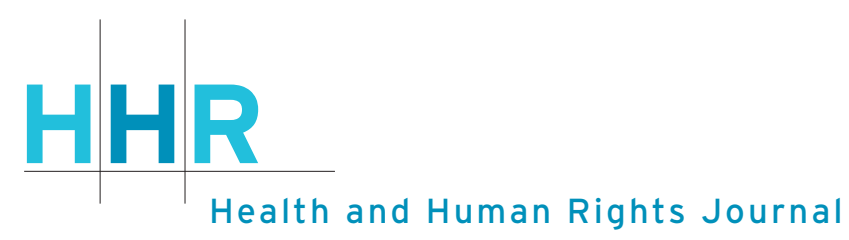

\title{
Litigating Reproductive Health Rights In The Inter- American System: What Does A Winning Case Look Like?
}

\author{
CIARA O'CONNELL
}

\begin{abstract}
Remedies and reparation measures emerging from the Inter-American System of Human Rights in reproductive health cases have consistently highlighted the need to develop, and subsequently implement, non-repetition remedies that protect, promote, and fulfill women's reproductive health rights. Litigation outcomes that determine there have been violations of reproductive rights are regarded as a "win" for health rights litigation, but when implementation fails, is a "win" still a win? There has been considerable success in litigating reproductive health rights cases, yet the Inter-American Commission on Human Rights and the Inter-American Court of Human Rights are not adequately equipped to follow up on cases after they have been won. Successful and sustainable implementation of reproductive health rights law requires incorporation of non-repetition remedies in the form of legislation, education, and training that seeks to remodel existing social and cultural practices that hinder women's enjoyment of their reproductive rights. In order for a reproductive health rights case to ultimately be a "winner," case recommendations and decisions emerging from the Commission and Court must incorporate perspectives from members of civil society, with the ultimate goal being to develop measurable remedies that address underlying obstacles to domestic implementation.
\end{abstract}

Ciara O'Connell is a Ph.D. Candidate in the Law School at the University of Sussex in the United Kingdom.

Please address correspondence to Ciara O’Connell. Email: c.o-connell@sussex.ac.uk.

Competing interests: None declared.

Copyright (C) 2014 O'Connell. This is an open access article distributed under the terms of Creative Commons Attribution Non-Commercial License (http://creativecommons.org/licences/by-nc/3.o/), which permits unrestricted non-commercial use, distribution, and reproduction in any medium, provided the original author and source credited. 


\section{Introduction}

Women's REPRODUCTIVE HEALTH rights violations are at the forefront of today's "war on women." As a result, reproductive rights litigation has increased in both domestic and international human rights arenas in order to protect women's enjoyment of their reproductive health rights. ${ }^{2}$ The impact of reproductive health litigation extends much further than the individual, with outcomes also affecting family, community, and society as a whole. ${ }^{3}$ In the inter-American region, the Inter-American System of Human Rights has increasingly adopted a gender perspective in its cases and reporting mechanisms, with a noted progression in admitting and reviewing reproductive rights cases. ${ }^{4}$ In doing so, the Inter-American Commission on Human Rights ("the Commission") and the Inter-American Court of Human Rights ("the Court") have become forums for the advancement of domestic reproductive rights laws, policies, and practices. ${ }^{5}$ Reproductive health rights litigation emerging from the Inter-American System of Human Rights ("the Inter-American System") has been successful in recognizing State responsibility for rights violations, but has fallen short in implementing remedies that are designed to ensure non-repetition of violations. ${ }^{6}$ The Commission and Court have issued reparations and remedies in reproductive rights cases, but a failure to design, implement, and enforce non-repetition remedies in the aftermath of a winning reproductive rights case has significantly debilitated the impact of case outcomes.

The objective of this article is two-fold: first, to examine trends in remedies and reparation measures, with emphasis being placed on the importance of design and implementation of non-repetition remedies to fulfill women's reproductive health rights; and second, to use reports and case law from the Inter-American System to highlight inconsistencies in remedy design, as well as to identify possible areas for improvement, such as increased collaboration with members of civil society. The final section analyzes remedies developed in Paulina del Carmen Ramírez Jacinto v. México, a reproductive health rights case from the Commission, in order to understand the importance of effective non-repetition remedy design and its subsequent application at the national level.

\section{The Inter-American System and implementation}

The Inter-American System of Human Rights entrusts two treaty-monitoring bodies with the protection, promotion, and fulfillment of human rights in the Americas: the Inter-American Commission on Human Rights (1959) and the Inter-American Court of Human Rights (1979). ${ }^{7}$ The two bodies share the mission of advancing human rights in the region, but their duties, responsibilities, jurisdiction and powers of enforcement vary. The Commission accepts petitions filed on behalf of victims, determines admissibility of cases, and in some cases reviews Friendly Settlement Agreements (FSA) forged by the State and petitioners, where final conditions of the agreement include remedies and reparation measures. In the event that an agreement cannot be reached between the parties, either before or after the Commission has determined admissibility, the Commission issues a Merits Decision, which includes a list of recommendations with which the State must comply. If the State Party then fails to implement the elements of the agreement or decision, the Commission can elect to submit the case to the Inter-American Court. ${ }^{8}$ The Court reviews the materials and calls upon the State and the petitioner to give further information about the status of the case, which includes participation in the form of amicus curiae briefs submitted by interested parties. The judgment issued by the Court is binding on the State, and as such, the remedies delineated by the Court must be implemented by the State in their entirety. ${ }^{9}$ While this process is straightforward in theory, State implementation of remedies is lacking 
in application. Although the Commission publishes FSAs and issues Merits Decisions, and the Court orders remedies at the conclusion of a winning case, the Inter-American System does not operate a permanent and formal implementation-monitoring body to follow up on State compliance.

\section{Remedies and compliance}

The Open Society Justice Initiative's analysis of remedies designed by the Commission and Court and then implemented by the State analyzes both the types of remedies issued, as well as State implementation rates. ${ }^{10}$ The research, referring to findings developed by the Association for Civil Rights (ADC study), designates three categories of remedies: individual remedies that include pecuniary damages, orders to investigate human rights violations and punishment of perpetrators, and non-repetition measures. ${ }^{11}$ In reviewing the implementation of remedies from the Commission and Court between 2001 and 2006, the study found that the greatest levels of State implementation were in the form of monetary reparations, with a rate of $58 \%$ full implementation. ${ }^{12}$ Symbolic reparations, those intended to commemorate the victims of human rights abuses, were ordered in $21 \%$ of Commission and Court remedies and implemented $52 \%$ of the time. ${ }^{13}$ Investigation of abuse and punishment of perpetrators at the domestic level represent $13 \%$ of the remedies ordered by the Commission and Court, however it is estimated that only $10-14 \%$ of these remedies were fully implemented. ${ }^{14}$ Non-repetition remedies have the purpose of addressing the root causes of human rights violations, especially when the violation is a result of a systemic and widespread problem. These remedies include legislative reform, training and education programs, community-wide remedies, and raising social awareness. Although it can be argued that non-repetition remedies are fundamental to the promotion, protection, and fulfillment of human rights, only $9 \%$ of remedies issued by the Commission and Court included legal reform, where States made no effort to implement these remedies in approximately $75 \%$ of cases. ${ }^{15}$ Training and education of public officials achieved greater success in implementation, with $42 \%$ of remedies being fully implemented, yet the Commission and Court only issued these types of remedies in an estimated $3 \%$ of cases. ${ }^{16}$ Finally, remedies that aim to promote social awareness were ordered in only $2 \%$ of cases, but were implemented at a rate of $43 \%{ }^{17}$ These numbers represent implementation rates from cases emerging from the Inter-American System between 2001 and 2006, yet they clearly reflect a trend in how the Inter-American System designs its remedies, as well as in how the State interprets which remedies are worthy of implementation. Remedy design is particularly noteworthy in determining the potential efficacy of remedy implementation, because if the Commission and Court disregard the importance of strong, measurable remedies, the State will respond accordingly.

When a State fails to comply with remedies outlined by the Commission and Court, the Commission and Court then face the task of defining what kind of implementation is enough for a State to be compliant with the conditions of the agreement, decision, or judgment. The most detectable cases, in terms of monitoring compliance, are cases with remedies that call for monetary compensation, judicial measures, legislative reform, and training programs; compliance that is easy to see. Those remedies that call upon States to implement non-repetition measures that address less tangible causes of human rights violations often escape compliance monitoring because they are more difficult to assess. For example, remedies that are designed to eradicate social norms that reinforce discrimination are far more difficult to measure than a monetary payment to an individual petitioner. The Court has noted the importance of incorporating remedies that include guarantees of non-repetition, by declaring that the State has a general obligation to ensure the "elimination of norms and practices of any type that result in violations of the guarantees established in the (American) Convention, as well as the enactment of laws and the development of practices conducive to the effective observance of these guarantees." 18

\section{Remedies and reproductive rights}

Before commencing an analysis of reproductive 
health rights and remedies, it is imperative to determine the competence of the Commission and Court in finding a violation of the right to health. Although the American Convention of Human Rights does not contain a directly justiciable provision on the right to health, the right is enshrined in numerous international human rights treaties. ${ }^{19}$ In addition, the Inter-American System has developed the right to health in its own regional treaties, as well as in its work through jurisprudence and reporting mechanisms. ${ }^{20}$ As human rights law has evolved, the justiciability of the right to health, as well as other economic, social, and cultural rights, has become recognized as indivisible in nature from justiciable civil and political rights, such as those delineated in the American Convention. Monica Feria Tinta illustrates this point clearly when she notes, “ $(j)$ usticiability is no longer a matter of perfectly dissecting and distinguishing the inseparable: 'here is the right to life and the right to health' or 'here is freedom from torture' and here 'the right not to be starved." ${ }_{21}$ The Court demonstrated this logic when it drew connections between a reproductive health right and rights to privacy and family life in the contentious Artavia Murillo et al v. Costa Rica case. $^{22}$ Therefore, although the American Convention does not explicitly protect the right to health, it is very much understood as being integral to the promotion and fulfillment of justiciable civil and political rights. Then, in using this rationale, the right to reproductive health-as it is an element of the right to health-is integral to the implementation of women's more justiciable civil and political rights.

\section{Reproductive health is defined as}

a state of complete physical, mental, and social well-being and not merely the absence of disease or infirmity, in all matters relating to the reproductive system and to its functions and processes. Reproductive health therefore implies that people are able to have a satisfying and safe sex life and that they have the capability to reproduce and the freedom to decide if, when and how often to do so. Implicit in this last condition are the rights of men and women to be informed and to have access to safe, effective, affordable and acceptable methods of family planning of their choice, as well as other methods of their choice for regulation of fertility which are not against the law, and the right of access to appropriate health-care services that will enable women to go safely through pregnancy and childbirth and provide couples with the best chance of having a healthy infant (emphasis added). ${ }^{23}$

Non-repetition remedies are fundamental to the protection and promotion of women's reproductive health rights because reproductive rights violations are directly connected to underlying sociocultural practices that place women in a position of less power. ${ }^{24}$ These practices limit women's freedom to access information and education, and to take part in their own decision making. The Inter-American System's jurisprudence has "evolved from a concept of formal equality toward one of substantive equality," meaning that States are increasingly facing pressure to take positive action in implementing human rights. ${ }^{25}$ This evolution is often challenged, where the competence of international human rights monitoring bodies to issue substantive reparations, such as remedies that address discrimination, is contested, as it infringes upon state sovereignty. ${ }^{26}$ However, the principles of human rights law require that human rights not only be protected, but also promoted and fulfilled, which requires the organs of the Inter-American System to develop reasoning and remedies that serve to achieve substantive equality, and subsequently, measures that have the purpose of effectively ensuring implementation of human rights.

While the argument to support further development of non-repetition remedies in reproductive rights cases is compelling, the Inter-American System does not exert substantial pressure on States to implement remedies that address structural problems, which ultimately serves as a green light for future reproductive rights violations. The Commission recognizes the necessity of developing effective non-repetition remedies that address sociocultural norms and attitudes in women's rights cases, and incorporates language to that effect, such as the 
need to "change laws and public policies on reproductive health and family planning, eliminating any discriminatory approach and respecting women's autonomy," or developing a "reform process that will put an end to the condoning by the State of domestic violence against women... and discrimination in the handling thereof." ${ }^{27}$ However, State implementation of these types of remedies has been either nonexistent or ineffectual. ${ }^{28}$ In addition, because the Commission and Court lack the mechanisms to effectively monitor compliance, organizations from civil society and national Ombuds Offices play an essential role in assessing State implementation efforts, permitting the State to focus on efforts that can be clearly measured (those remedies that are easy to see). ${ }^{29}$

Applying the implementation trends determined by the ADC study to reproductive rights case law illustrates fundamental flaws in the design of non-repetition remedies. As much as the Commission and Court recognize the benefits of developing remedies designed to address women's discrimination and inequality, development of non-repetition remedies that address structural causes of women's rights violations have not been designed with the intent of being realistically measurable, giving the State freedom to ignore these remedies. In the case of reproductive health rights, the focus of remedy design rests almost entirely on individual pecuniary damage remedies, symbolic reparations, legislative reform, and training programs for health and judiciary professionals, with little emphasis being placed on measurable non-repetition remedies that address systemic problems in areas such as education systems. ${ }^{30}$ Because non-repetition of reproductive rights violations is contingent on a remodeling of structural social and cultural norms, remedies that have the purpose of confronting these norms must be designed in such a way that implementation can be assessed and measured. ${ }^{31}$ The following sections highlight reproductive rights reports and case law from the Inter-American System in order to demonstrate how the Commission and Court interpret reproductive rights violations and then design remedies.

\section{The Inter-American System and reproductive health rights}

Through its conventions, reporting mechanisms, and judicial proceedings, the Inter-American System has developed a comprehensive understanding of the challenges that impede the implementation of reproductive health rights for women. These challenges include subordination of women in both the public and private spheres, socio-cultural practices that place women's role as mothers before their role as an autonomous individual, and stereotypes, policies, and practices that give control and decision-making power to men. ${ }^{22}$ Ruth Rubio-Marin, in her work on gender and reparations, discusses these structures as having a "compound effect... [where] violence, discrimination, and exploitation that women and girls are subject to...becomes most vivid when we examine the gendered nature of the harms that women endure and the short and long-term effects on their lives." 33 For Rubio-Marin, design of remedies should have as part of their aim, a challenging of the status quo, in order to address conditions of discrimination, violence, and poverty. The Inter-American Court has identified the impact of such practices as being detrimental to women's ability to access justice, where the stereotyping of women based on their gender is both a cause and consequence of violence against women. ${ }^{34}$ The Inter-American Convention on the Prevention, Punishment, and Eradication of Violence Against Women recognizes the inherent structural challenges women face in enjoying their rights, by calling on States Parties to

modify social and cultural patterns of conduct of men and women, including the development of formal and informal educational programs appropriate to every level of the educational process, to counteract prejudices, customs and all other practices which are based on the idea of the inferiority or superiority of either of the sexes or on the stereotyped roles for men and women which legitimize or exacerbate violence against women. ${ }^{35}$ 
Furthermore, Inter-American System reporting mechanisms such as annual and thematic reports, emphasize those themes mentioned above by referring to structural factors such as gender stereotyping in the health sector, and "discriminatory socio-cultural patterns that present a risk to women's health." 36 The report entitled, Access to Information on Reproductive Health from a Human Rights Perspective, elaborates on the effects of discrimination on women's enjoyment of reproductive health by referring to "needs that some groups of women may have due to contexts of exclusion, marginalization or discrimination, including indigenous and Afro-descendant women, adolescent girls, women who live in rural areas and migrant women." ${ }^{37}$ The rhetoric surrounding social and cultural practices that contribute to women's discrimination and inequality is also prevalent in reproductive rights cases emerging from the Inter-American System, and in particular the Inter-American Commission.

A Friendly Settlement Agreement (FSA) in the case of María Mamerita Mestanza Chávez v. Perú set a precedent for identifying discrimination as being a basis for women's reproductive rights violations. ${ }^{38}$ This case involved the death of an indigenous woman who was forcibly sterilized as part of a national population control policy. ${ }^{39}$ She agreed to the sterilization procedure only after receiving threats of financial repercussions due to the large number of children in her family. In the FSA, the Peruvian State pledged to "change laws and public policies on reproductive health and family planning, eliminating any discriminatory approach and respecting women's autonomy." ${ }^{40}$ Provision $11(\mathrm{~b})(2)$ of the FSA is an evident non-repetition measure designed to address structural discrimination, where the state agreed to implement "training courses for health personnel in reproductive rights, violence against women, domestic violence, human rights, and gender equity, in coordination with civil society organizations that specialize in these topics." ${ }^{41}$ This element of the agreement does suggest State cooperation with civil society as a component of domestic implementation efforts, but fails to fully address structural factors that exist outside of the healthcare sector. The agreement reached in this case is of the utmost importance to the development of reproductive rights litigation in the Inter-American System because, although it was not successful in eliminating discrimination, it laid groundwork for designing remedies that address structural factors in future cases.

Much like the previous case, Paulina del Carmen Ramírez Jacinto v. México resulted in an FSA. ${ }^{42}$ In this case, a 14-year-old girl became pregnant after being raped by an intruder in her home. Under Mexican law, Paulina was entitled to exercise her right to abortion in the case of rape, but after deciding to do so, she faced manipulation, coercion, and misinformation on behalf of the health center staff, as well as from representatives of the Catholic Church. As a result, the victim's mother, fearing for the safety of her daughter and financial threats issued by the hospital, refused the procedure. The reproductive rights violations in this case highlight sociocultural norms, values, and practices that exist within the health care sector. The agreement came four years after the advancements made in the Chávez case, yet the Paulina del Carmen Ramírez Jacinto v. México FSA made no mention of reproductive rights, and failed to refer to practices within the health care system that contribute to reproductive rights violations. In the FSA's most promising provision, the State agreed to assess implementation of its National Program for the Prevention and Attention of Domestic, Sexual, and Violence Against Women. However, the FSA did not directly note the correlation between religion and the attitudes and beliefs held by health care practitioners as being associated with reproductive rights violations. ${ }^{43}$ This case is discussed in more detail in the following section to examine remedy development and implications at the national level.

More recently, the Inter-American Court issued a judgment in Artavia Murillo et al. v. Costa Rica, where the Court ordered a reversal of legislation that banned in vitro fertilization (IVF). ${ }^{44}$ The State of Costa Rica banned IVF in 2000 , on the grounds that an executive decree authorizing IVF in 1995 was unconstitutional as it violated the right to life. ${ }^{45}$ This reasoning was heavily influenced by pressure from the Catholic Church, which maintains the ar- 
gument that the right to life applies to the unborn. ${ }^{46}$ The Inter-American Court determined that the State had violated the petitioners' rights to privacy and family life, and concluded that the right to life of an unfertilized ovum did not supersede these rights. ${ }^{47}$ Although the advancements in this case are significant in regards to defining reproductive health, the Court neglected to fully address the root causes of the violation in its reparations. These causes are directly connected to the relationship that exists between the Catholic Church and the State, and also societal norms of inequality, discrimination, and violence that are disproportionately harmful to women..$^{4}$ In the development of its argument, the Court paid particular attention to "indirect discrimination in relation to gender," where the Court explored the effects of infertility as it relates to a gender identity model that emphasizes women's role as mothers, and infertile men as having "a strong sense of impotence." 49 The Court clearly states in its considerations that "these gender stereotypes are incompatible with international human rights law and measures must be taken to eliminate them." 50 However, concerning non-repetition remedies, the Court failed to reflect on its conclusions surrounding gender, and did not issue reparation to that effect. Instead, the Inter-American Court's judgment addressed the rights of persons with reproductive disabilities by ordering the State to "raise awareness on reproductive health... to implement permanent education and training programs and courses on human rights, reproductive rights and non-discrimination for judicial employees in all areas..." ${ }_{51}$ In this remedy, the inability to reproduce without assistance is seen as a disability in itself, where the argument to raise awareness of reproductive health is developed on grounds of discrimination against those with disabilities.

Each of the above reproductive rights cases does not comprehensively incorporate a gendered approach to understanding and addressing the root causes of reproductive rights violations. As a result, the non-repetition remedies approved by the Commission and designed by the Court neglect to address sociocultural practices which contribute to women's discrimination and inequality. In the case of María Mamerita Mestanza Chavez v. Peru, the FSA reached by the petitioner and the State of Peru was more progressive in pushing for agreement conditions that recognized discrimination and violence against women, but this anomaly in progressive remedy design can perhaps be attributed to the armed conflict context in which the violation occurred..$^{2}$ In looking at the Inter-American System reporting mechanisms, conventions, and reproductive rights cases, there is an obvious disconnect between rhetoric and practice. While the Inter-American System clearly acknowledges that reproductive rights violations are a result of structural inequality, little is done on behalf of the Commission or Court to urge States to implement reform.

To further emphasize the importance of designing effective non-repetition remedies in reproductive health rights litigation, the final section explores possible opportunities for the improvement of remedy design and implementation. A deeper analysis of the above-mentioned case, Paulina del Carmen Ramírez Jacinto v. México serves to elucidate the challenges of putting paper into practice to develop a winning case.

\section{Paulina del Carmen Ramírez Jacinto v. México-a winning case?}

The Paulina del Carmen Ramírez v. México FSA lends itself to an analysis for several reasons. First, legal abortion is a contentious issue throughout the Inter-American region, where Mexico City is the sole location in Mexico for a woman to obtain an abortion, ${ }^{53}$ and where there also exists a significant conscientious objection movement. ${ }^{54}$ Second, the FSA incorporates a non-repetition remedy in the form of implementation of a national law that requires the State of Mexico to address sociocultural attitudes and norms that discriminate against women. Finally, the FSA was completed more than seven years ago, where it can be expected that the State would have taken significant steps to comply with the terms of the agreement.

In the conclusion of the Paulina del Carmen Ramírez v. México FSA, the Commission reinforces 
its commitment to women's rights by stating: "protecting and promoting the rights of women is a priority for OAS member states, with the goal of ensuring the full and effective enjoyment of their basic rights, in particular the rights of equality, to freedom from discrimination, and to a life free from gender-based violence." 55 This excerpt harkens back to language in reports from the Commission's Special Rapporteur on the Rights of Women; however, the remedies developed in this agreement do not fully support these objectives. ${ }^{56}$ A review of the types of remedies agreed upon in this FSA, as well as their application at the domestic level, highlights both shortcomings and areas for potential improvement in developing remedies that address underlying sociocultural factors that impede full enjoyment of reproductive health rights.

In Paulina del Carmen Ramírez v. México, the FSA affirms that the "nation's laws lack regulations that allow rape victims to exercise their right to an abortion, they (women) are compelled to carry to term pregnancies imposed on them by force that, among underage mothers, are characterized by high levels of risk." ${ }^{57}$ Although women in Mexico do have the right to abortion in the event of rape, the law is not implemented effectively, meaning that it does not provide women with the intended protection of their rights. Because the State failed to regulate and implement the law successfully, the violation of the right to abortion is the responsibility of the State. In this case, the FSA included nine individual remedies, eight non-repetition remedies and no justice measures. ${ }^{5}$ Of the nine individual remedies, reparation in the form of monetary compensation accounted for six: State funding of the petitioner's legal expenses; education and school supplies for the petitioner's child; a one-time payment to assist with the establishment of a microenterprise for the petitioner; moral damages; and funds toward purchasing a home. ${ }^{59}$ In addition, individual compensation includes nonmonetary remedies, such as the distribution of a computer and printer, and health services that include psychological care. ${ }^{60}$ Non-repetition remedies in this agreement take several forms, including: legislative proposals, public acknowledgment of the violation, training courses to be conducted by the petitioners, a review of literature and materials to detect any shortcomings in the way reproductive health information is delivered, and dissemination of a circular to the health sector to strengthen the commitment toward ending violence against women. ${ }^{61}$ Of these non-repetition remedies, the ones with the greatest potential to address sociocultural factors that hinder implementation of women's reproductive rights law are those that aim to confront causes of discrimination and inequality. In this agreement, the following provisions fall within that criteria, if only minimally:

(i) Eleven: The local government agrees to schedule the training courses to be conducted by the petitioners... ${ }^{62}$

(ii) Twelve (1): Conduct a national survey, involving state representation, to assess the enforcement of Official Mexican Standard NOM 190-SSA11999 regarding medical assistance in cases of domestic violence, and to measure progress with the implementation of the National Program for the Prevention and Attention of Domestic, Sexual, and Violence Against Women (emphasis added). ${ }^{63}$ (iii) Twelve (4): Through the National Center for Gender Equality and Reproductive Health, conduct a review of books, indexed scientific articles, postgraduate theses, and documented governmental and civil society reports dealing with abortion in Mexico, in order to prepare an analysis of the information that exists and detect shortcomings in that information... ${ }^{64}$

The above remedies are designed to focus on women's inequality and discrimination, yet they do not effectively call for a remodeling of social and cultural norms. By reviewing these remedies in terms of monitoring their implementation, the following conclusions can be made: local government training is a remedy that is relatively simple to implement, as well as to measure. If the State coordinates training sessions, it is compliant in fulfilling that element of the FSA. However, it is important to note that the quality, duration, and content of the training programs is not elaborated 
upon in the recommendation. Similarly, conducting a national survey is a tangible remedy that can be implemented and assessed with relative ease. The same is true of the remedy that compels the State to review books and other written materials. The State can create a department with the purpose of fulfilling the requirements of this remedy, and can then report back to the Commission and petitioner that the conditions of the agreement have been fulfilled. However, the second part of remedy 12(1), measure progress with the implementation of the National Program for the Prevention and Attention of Domestic, Sexual and Violence Against Women, is far more challenging to implement, and subsequently measure. ${ }^{65}$

The second part of remedy 12(1) is of significant importance due to its potential to address socio-cultural norms that inhibit women's enjoyment of reproductive health rights. The operational word, "measure," implies that the State must report back to the Commission and petitioner with evidence and information about how the elements of the National Program for the Prevention and Attention of Domestic, Sexual, and Violence Against Women (National Program) are being implemented. However, the agreement does not define how the State should measure implementation. The National Program includes the implementation of Official Mexican Standard NOM-046-SSA2-2005, "Criteria for the Protection and Care of Domestic and Sexual Violence Against Women for the National Health System." ${ }^{66}$ Of the numerous provisions delineated within this legislation, section 6.8.1 affirms a duty "to investigate conduct in public institutions, specifically in regards to domestic or sexual violence, to better enable the quantification and identification of its causes and underlying social, cultural and economic, associated factors, as well as their impact on individual and collective health (emphasis added)." ${ }^{67}$ According to the terms agreed upon in the FSA, this provision, as part of the National Program, must be implemented and subsequently measured in order for the State to be compliant with the conditions of the agreement. However, the design of this remedy is developed in such a way that implementation of section 6.8.1 cannot be measured realistically. Fur- thermore, section 5.3 of the National Program states that health institutions must "foster coordination with other institutions, agencies and organizations in the public, social and private sectors in order to incorporate individuals involved with domestic or sexual violence, so that a collaboration of their respective powers provides women with the best possible care." ${ }^{68}$ This provision notes the importance of civil society's role in developing effective care mechanisms, with specific emphasis being placed on fostering coordination between different specialist groups in order to establish health institutions that incorporate a gendered approach to care. The National Program identifies the relationship between implementation of law and cooperation between the legal system and domestic institutions, agencies and organizations as being integral to the successful protection and fulfillment of women's rights. Although the National Program develops provisions to address women's rights violations at the structural level, the Inter-American System does not adequately investigate implementation of this type of non-repetition remedy.

Much like the State concludes in section 5.3 of the National Program, there is a practical necessity for collaboration between legal systems and civil society in designing remedies that compel implementation of non-repetition remedies. ${ }^{69}$ In the 1999 Guidelines for Participation of Civil Society Organizations in OAS Activities (Guidelines), civil society organizations are "understood to mean any national or international institution, organization, or entity made up of natural or juridical persons of a nongovernmental nature." ${ }^{\circ}$ The Guidelines discuss a tradition of OAS cooperation with civil society organizations (that) is based on the significant contributions these organizations can make to OAS work, since they can contribute knowledge and additional information to decision-making processes, raise new issues and concerns that will subsequently be addressed by the OAS, lend expert advice in their areas of expertise, and contribute to consensus-building in many spheres. ${ }^{71}$

The duty of civil society in the process of human rights litigation has been to inform the Commission and Court about the human rights violation, 
and the context within which it occurred. While the Commission and Court incorporate contextual information given by civil society organizations into their work, the place for civil society to enter the discussion during the remedy design stage of a case is limited. If, for instance, representatives from civil society had played a greater role in formulating the provision above, to "measure progress with the implementation of the National Program for the Prevention and Attention of Domestic, Sexual, and Violence Against Women," the word "measure" may have taken on more meaning. ${ }^{72}$ For example, section 6.8.1 of the National Program has the objective of identifying and quantifying underlying social, cultural, and economic factors that contribute to violence against women, with specific emphasis on health care. However, implementation of this provision cannot be achieved, let alone measured, without the cooperation of civil society members. There are organizations working in the region that focus on women's health rights that would be well-suited to collaborate with the State in designing education programs for both the healthcare sector and the public education system. ${ }^{73}$ The most effective way for the Commission and Court to then monitor compliance with the National Program, and subsequently provision 12(1), would be to include in the remedy the requirement for the State to submit reports that outline cooperation efforts initiated by the relationships forged with members of civil society.

\section{Conclusion: What does a winning case look like?}

A winning reproductive rights case in the Inter-American System is one that includes non-repetition remedies that are designed with measurable implementation as a primary goal. As has been argued in this article, insufficient state implementation of non-repetition remedies is in part attributable to ineffective remedy design. In accepting this claim, it is then imperative to design remedies that have the intention of not only protecting and promoting women's reproductive rights, but also fulfilling them. The most promising way to develop effective remedies is to foster further collaboration between the Commission and Court and civil society. While the contributions by civil society members to the advancement of case law before the Commission and Court cannot be underestimated, there is a much greater role for their participation in designing remedies. Women's reproductive rights organizations are familiar with the challenges that women face in accessing their rights, and have a level of expertise from which the Inter-American System can greatly benefit. However, in order for civil society to play a larger role in the development of non-repetition remedies, there must be a greater effort on their part to join that discussion. As much as the Commission and Court would benefit from incorporating the knowledge of civil society in the design and supervision of remedies, members of civil society have a responsibility to advocate for their inclusion.

Each of the cases mentioned above highlights the importance of understanding the role of underlying causes in perpetuating reproductive rights violations, yet the Commission and Court fail to supplement that understanding with measurable action. A winning reproductive rights case is one that does not end on judgment day, but that has a ripple effect that reaches far wider than the immediate reproductive rights violation. If the intent of the Inter-American System of Human Rights is to protect, promote, and fulfill human rights in the Americas, the Commission and Court must develop ways to effectively prevent reproductive health rights violations using non-repetition remedies that address systemic challenges, instead of relying solely on individual compensation and reparation to address structural rights violations.

\section{Acknowledgments}

The author wishes to thank the lecturers and fellow participants from the 2013 Health Rights Litigation course at the François-Xavier Bagnoud Center for Health and Human Rights for inspiring this paper. I also wish to thank the International Institute for the Sociology of Law in Oñati, Spain, for a quiet space within which to research and write. Finally, 
thank you to Jo Bridgeman, Charlotte Skeet, Vinodh Jaichand, and the reviewers for their helpful comments.

\section{References}

1. "War on women" is a phrase being used in the US and internationally to describe legislative and rhetorical attacks on women's rights. American Civil Liberties Union, Blog of Rights: War on Women. Available at https://www.aclu.org/ blog/tag/war-women.

2. Health rights litigation has increased significantly since the 1990s. S. Gloppen, "Litigation as a strategy to hold governments accountable for implementing the right to health," Health and Human Rights: An International Journal 10/2 (2008), pp. 21-36.

3. R. Cook, B.M. Dickens, and M. F. Fathalla, Reproductive Health and Human Rights: Integrating Medicine, Ethics, and Law (Oxford: Clarendon Press, 2003), p. 13.

4. Reproductive rights cases: Monica Carabantes Galleguillos v. Chile, Friendly Settlement Agreement, Inter-Am. Comm. H.R., Report No. 33/02 (2002); María Mamérita Mestanza Chávez v. Perú, Friendly Settlement Agreement, Inter-Am. Comm., Report No. 71/03 (2003); Paulina del Carmen Ramírez Jacinto v. México, Friendly Settlement Agreement, Inter-Am. Comm., Report No. 21/o7 (2007); I.V. v. Bolivia, Admissibility, Inter-Am. Comm. H.R., Report No. 40/08 (July 23, 2008), FS v. Chile, Admissibility, Inter-Am. Comm. H.R., Report No. 52/14 (July 21, 2014); and Artavia Murillo et al. ("In vitro fertilization") v. Costa Rica, Preliminary Objections, Merits, Reparations and Costs, Judgment, Inter-Am. Ct. H.R. (ser. C) No. 257 (November 28, 2012). Reproductive rights cases submitted to the Commission include, AN v. Costa Rica (2008), Beatriz v. El Salvador (2013), and Aurora v. Costa Rica (2013).

5. Inter-American Commission Member States. Available at http://www.oas.org/dil/treaties_B-32_American_ Convention_on_Human_Rights_sign.htm.

6. Velasquez Rodriguez v. Honduras, Merits, Judgment, Inter-Am. Ct. H. R. (ser. C) No. 4 (July 29, 1988) paras. 165166. This case is of significant importance to the Court's future proceedings because it relates individual events with a systemic problem. L. Cabal, M. Roa, and L. Sepúlveda-Oliva, "What Role can International Litigation Play in the Promotion and Advancement of Reproductive Rights in Latin America?" Health and Human Rights: An International Journal 7/1 (2003), p. 56.

7. For a thorough discussion of the Inter-American System of Human Rights, see, J. M. Pasqualucci, The Practice and Procedure of the Inter-American Court of Human Rights, $2^{\text {nd }}$ ed. (New York: Cambridge University Press, 2013).

8. Ibid., Chapter 3.

9. Ibid., p. 27.
10. Open Society Justice Initiative, Judgment to Justice: Implementing international and regional human rights decisions, (New York: Open Society Foundation, 2010), p.19.

11. F. Basch et al., Asociación por los Derechos Civiles (ADC Study), “The Effectiveness of the Inter-American System for the Protection of Human Rights: Quantitative Approach on the System's Operation and the Compliance with its Decisions," Sur International Journal of Human Rights 7/12 (June 2010), pp. 9-35.

12. Ibid., p.18.

13. Ibid., pp. 15 and 18 .

14. Ibid., p.15; and Judgment to Justice (see note 10), p. 68, drawing upon conclusions from the ADC Study.

15. ADC Study (see note 11), pp. 15 and 19, Graph 4.

16. Ibid., pp. 15 and 18.

17. Ibid.

18. Claude Reyes et al. v. Chile, Merits, Reparations and Costs, Judgment, Inter- Am. Ct. H.R. (ser. C) No. 151 (September 19, 2006), para. 163.

19. American Convention on Human Rights, O.A.S. Treaty Series No. 36 (1969). Available at http://www.oas.org/dil/ treaties_B-32_American_Convention_on_Human_Rights_ sign.htm; International Covenant on Economic, Social and Cultural Rights (ICESCR), G.A. Res. 2200A (XXI), Art. 12. (1966). Available at http://www.ohchr.org/EN/ProfessionalInterest/Pages/CESCR.aspx; International Convention on the Elimination of All Forms of Discrimination against Women, G.A. Res. 34/180, Art. 14. (1979). Available at http:// www.ohchr.org/Documents/ProfessionalInterest/cedaw. pdf; Convention on the Rights of the Child (CRC), G.A. Res. 44/25, Art. 24. (1989). Available at http://www.ohchr. org/en/professionalinterest/pages/crc.aspx; Convention on the Rights of Persons with Disabilities, G.A. Res, 61/106, Art. 25. (2006). Available at http://www.un-documents.net/ a61r106.htm.

20. Additional Protocol to the American Convention on Human Rights in the Area of Economic, Social and Cultural Rights (Protocol of San Salvador), Art. 10. (1988). Available at http://www.oas.org/juridico/English/Treaties/a-52.html; Access to Justice for Women Victims of Sexual Violence: Education and Health (2011). Available at http://www.oas. org/en/iachr/women/docs/pdf/sexualviolenceeduchealth. pdf; Access to Information on Reproductive Health from a Human Rights Perspective (2011). Available at http://www. oas.org/en/iachr/women/docs/pdf/womenaccessinformationreproductivehealth.pdf; Access to Maternal Health Services from a Human Rights Perspective (2010). Available at http://www.oas.org/en/iachr/women/docs/pdf/MaternalHealth2010.pdf; and Guidelines for Preparation of Progress Indicators in the Area of Economic, Social and Cultural Rights (2008). Available at http://cidh.org/pdf files/Guidelines final.pdf.

21. M. Feria Tinta, "Justiciability of Economic, Social and Cultural Rights in the Inter-American System of Protection 
of Human Rights: Beyond Traditional Paradigms and Notions," Human Rights Quarterly, 29/2 (2007), p. 435.

22. Artavia Murillo et al. v. Costa Rica, Merits, Reparations and Costs, Judgment, Inter-Am. Ct. H. R. (ser. C) No. 257 (November 28 2012) paras. 142-147. This case is an in vitro fertilization case, where the Court developed its arguments to protect a reproductive right by finding state violations of the right to privacy (Art. 11) and the right to form a family (Art. 17) under the American Convention.

23. International Conference on Population and Development (ICPD) Report of the International Conference on Population and Development, September 5-13, 1994, UN Doc. No. A/CONF.171/13 (October 18, 1994).

24. J. Kaufman, "Measuring Reproductive Health: From Contraceptive Prevalence to Human Development Indicators," in L. Reichenbach and M.J. Roseman (eds), Reproductive Health and Human Rights: The way forward (Philadelphia: University of Pennsylvania Press, 2009), pp. 76-83.

25. V. Abramovich, "From Massive Violations to Structural Patterns: New Approaches and Classic Tensions in the Inter-American Human Rights System," Aportes DPLf - Reflections on Strengthening the Inter-American Human Rights System 16/5 (June 2012), p.26. Available at http:// www.scielo.br/scielo.php?pid=S1806-64452009000200002 \&script=sci_arttext\&tlng=en.

26. For a discussion of human rights law and state sovereignty, see K. Sikkink, "Human Rights, Principled Issue-Networks, and Sovereignty in Latin America," International Organization 47/3 (Summer 1993).

27. María Mamérita Mestanza Chávez v. Perú, Friendly Settlement Agreement, Inter-Am. Comm. H.R., Report No. 71/03 (2003), Part 4 at 11; and Maria da Penha Maia Fernandes v. Brazil, Friendly Settlement Agreement, Inter-Am. Comm. H.R., Report No. 54/01 (2001), Part VIII Recommendations at 4

28. ADC Study (see notes 11-17).

29. Ombuds offices are responsible for working with the Inter-American System and the State to implement human rights protections. Civil society organizations work alongside victims ("petitioners") to report back to the Commission and Court in regards to the State's efforts to comply with the terms of the agreement or decision. For such an example see, Paulina del Carmen Ramírez Jacinto v. México, Friendly Settlement Agreement, Inter-Am. Comm., Report No. 21/07 (2007); Part V, Determination of Compatibility and Compliance.

30. ADC Study (see note 11), p. 15.

31. Kaufman (see note 24), p. 86.

32. Center for Reproductive Rights, Bodies on Trial: Reproductive Rights in Latin American Courts, (New York, 2003), p.13. Available at http://reproductiverights.org/en/ document/bodies-on-trial-reproductive-rights-in-latin-american-courts; S. Chant, "Gender, Families and Households," in S. Chant and N. Craske (eds), Gender in
Latin America (London: Latin America Bureau, 2003), p. 167.

33. R. Rubio-Marín, "The Gender of Reparations in Transitional Societies," in R. Rubio-Marín (ed), The Gender of Reparations: Unsettling Sexual Hierarchies While Redressing Human Rights Violations (Cambridge: Cambridge University Press, 2009), p. 91.

34. González et al. ("Cotton Field") v. México, Preliminary Objections, Merits, Reparations and Costs, Judgment, Inter-Am. Ct. of H. R. (ser. C) No. 205 (November 16, 2009), paras. 400 and 401.

35. Inter-American Convention on the Prevention, Punishment and Eradication of Violence Against Women, (1994). Available at http://www.cidh.org/Basicos/English/ basic13.Conv of Belem Do Para.htm.

36. Special Rapporteur on the Rights of Women, Access to Maternal Health Services from a Human Rights Perspective, OEA/Ser.L/V/II. Doc. 69 (2010). Available at http:// cidh.org/women/SaludMaterna1oEng/MaternalHealthTOCeng.htm.

37. Special Rapporteur on the Rights of Women, Access to Information on Reproductive Health from a Human Rights Perspective, OEA/Ser.L/V/II. Doc. 61 (2011). Available at http://www.cidh.oas.org/pdf files/womenaccessinformationreproductivehealth.pdf.

38. María Mamérita Mestanza Chávez v. Perú, Friendly Settlement Agreement, Inter-Am. Comm. H.R., Report No. 71/03 (2003), Part 11.

39. This case was representative of over 300,000 women who were forcibly sterilized as part of President Fujimori's family planning program. For further discussion of this case see, V. Jaichand and C. O'Connell, "Bringing It Home: The Inter-American System and State Obligations - Using a gender approach regionally to address women's rights violations domestically," Inter-American and European Human Rights Journal, 3 (2010), pp. 58-67.

40. María Mamerita Mestanza Chávez v. Perú, (see note 38), part 4 at 11 .

41. Ibid., 11(b)(2).

42. Paulina del Carmen Ramírez Jacinto v. México, Friendly Settlement Agreement, Inter-Am. Comm., Report No. 21/07 (2007).

43. Ibid., Part 12, Sec. 4.

44. Artavia Murillo et al. v. Costa Rica (see note 22), paras. 71-76.

45. Ibid., para. 74; Judgment No. 2000-02306 (March 15, 2000), Constitutional Chamber of the Supreme Court of Justice, Costa Rica, Case file No. 95-001734-007-CO.

46. L. M. Morgan E. F.S. Roberts, "Reproductive Governance in Latin America," Anthropology \& Medicine, 19/2, (August 2012), p. 242.

47. Artavia Murillo et al. v. Costa Rica (see note 22), para. 273.

48. T. Johnson, "Guaranteed Access to Safe and Legal 
Abortions: The true revolution of Mexico City's legal reforms regarding abortion," Columbia Human Rights Law Review, 44/2 (2013), p. 443. Available at http://www.corteidh. or.cr/tablas/r30937.pdf; Paul Hunt, Expert Opinion, Order of the President of the Inter-American Court of Human Rights, Artavia Murillo et al. v. Costa Rica (August 6 2012), p. 9, para. 30. Available at http://www.corteidh.or.cr/docs/ asuntos/artavia_06_08_12_ing.pdf.

49. Artavia Murillo et al. v. Costa Rica (see note 22), paras. 294-301.

50. Ibid., para. 302.

51. Ibid., p. 98 , para. 341.

52. See, Final Report from the Peruvian Truth and Reconciliation Commission. Available at http://cverdad.org.pe/ ifinal/.

53. See D. Becker and C. Díaz Olavarrieta, "Decriminalization of Abortion in Mexico City: The effects on women's reproductive rights," American Journal of Public Health, 13/4 (April 2013), p. e1.

54. CMI Brief, "Access Denied: Abortion Rights in Latin America," 13/1 (January 2014), p. 2. Available at http://www. cmi.no/publications/file/5022-access-denied-abortionrights-in-latin-america.pdf; see also, T. Johnson, (see note 49), pp. 463-465.

55. Paulina del Carmen Ramírez Jacinto v. México, (see note 42$)$, para. 18 .

56. Access to Maternal Health Services from a Human Rights Perspective (see note 30 ) and Access to Information on Reproductive Health from a Human Rights Perspective (see note 31 ).

57. Paulina del Carmen Ramírez Jacinto v. México (see note 42), para. 14 .

58. Ibid. Although justice measures were not identified in the FSA, the public acknowledgment included in the agreement makes note of the domestic criminal case against Paulina's attacker.

59. Ibid., Remedies 1, 2, 3, 6, 8 and 9.

6o. Ibid., Remedies 4, 5, 7 .

61. Ibid., Remedies 10, 11, 12 (and subdivisions).

62. Ibid., Remedy 11.

63. Ibid., Remedy 12(1).

64. Ibid., Remedy 12(4).

65. Ibid., Remedy 12(1).

66. Norma Oficial Mexicana NOM-046-SSA2-2005, Violencia Familiar, Sexual y Contra Las Mujeres. Criterios para La Prevención y Atención, Gobierno Federal, Secretaría de Salud (Mexican Official Standard NOM-046-SSA2-2005, Sexual and Domestic Violence Against Women, Criteria for Prevention and Attention, Federal Government, Secretary of Health) (April 16, 2009). Available at http://www.dof.gob. $\mathrm{mx} /$ nota_detalle.php? $\operatorname{codigo}=5087256 \& \mathrm{fech} a=16 / 04 / 2009$. The previous Standard, NOM-190-SSA1-1999, was replaced by NOM-046-SSA2-2005.

67. Ibid., sec. 6.8.1. (All quotations from Spanish-lan- guage material have been translated from Spanish into English by the author).

68. Ibid., sec. 5.3.

69. Office of the High Commissioner for Human Rights, Working with the United Nations Human Rights Programme A Handbook for Civil Society (New York and Geneva, 2008), p. iii. Available at http://www.ohchr.org/en/AboutUs/CivilSociety/Documents/Handbook_en.pdf.

70. Organization of American States, Guidelines for Participation of Civil Society Organizations in OAS Activities, OEA/Ser.G, CP/RES. 759 (1217/99) corr.1 (December 15 1999), Available at http://www.oas.org/consejo/resolutions/ res759.asp; also, United Nations Human Rights Program - A Handbook for Civil Society (see note 68) defines civil society as including the following: Human rights defenders; Human rights organizations (NGOs, associations, victim groups); Related issue-based organizations; Coalitions and networks (women's rights, children's rights, environmental rights); Persons with disabilities and their representative organizations; Community-based groups (indigenous peoples, minorities); Faith-based groups (churches, religious groups); Unions (trade unions as well as professional associations such as journalist associations, bar associations, magistrate associations, student unions); Social movements (peace movements, student movements, pro-democracy movements); Professionals contributing directly to the enjoyment of human rights (humanitarian workers, lawyers, doctors and medical workers); Relatives of victims; and Public institutions that carry out activities aimed at promoting human rights (schools, universities, research bodies).

71. Ibid.

72. Paulina del Carmen Ramírez Jacinto v. México (see note 42), Remedy 12(1).

73. Selection of civil society organizations working on women's rights and reproductive rights in Mexico: GIRE, (Information Group for Reproductive Choice), Available at https://www.gire.org.mx/;Women's Global Network for Reproductive Rights (WGNRR), Available at http://www. wgnrr.org/; CLADEM (Latin American and Caribbean Committee for the Defense of Women's Rights), Available at http://www.cladem.org/; and Equidad, Available at http:// www.equidad.org.mx/. 